\title{
Analysis of Alterations in Selected Haematological Parameters of Ascariasis Patients in Umudike, Abia Stae, Nigeria
}

\author{
Emmanuel Ifeanyi Obeagu ${ }^{1 *}$, Getrude Uzoma Obeagu ${ }^{2}$, Udunma Olive Chijioke ${ }^{3}$, Igri B Ofor ${ }^{4}$ and \\ Grace I Amilo ${ }^{5}$ \\ ${ }^{1}$ Department of Health Services, Michael Okpara University of Agriculture, Umudike, Abia State, Nigeria \\ ${ }^{2}$ Department of Nursing Science, Ebonyi State University, Abakaliki, Ebonyi State, Nigeria \\ ${ }^{3}$ Department of Medical Laboratory Science, Faculty of Health Sciences and Technology, University of Nigeria, Enugu Campus, Enugu State, \\ Nigeria \\ ${ }^{4}$ Department of Medical Laboratory Science, Imo State University, Owerri, Nigeria \\ ${ }^{5}$ Department of Medical laboratory science, Nnamdi Azikiwe University, Nnewi Campus, Nnewi, Anambra State, Nigeria.
}

*Corresponding author: Emmanuel Ifeanyi Obeagu, Department of Health Services, Michael Okpara University of Agriculture, Umudike, Abia State, Nigeria, Tel: +2348037369912; E-mail: emmanuelobeagu@yahoo.com

Received: August 30, 2017; Accepted: September 20, 2017; Published: September 28, 2017

Citation: Obeagu El, Obeagu GU, Chijioke UO, Ofor IB, Amilo GI (2017) Analysis of Alterations in Selected Haematological Parameters of Ascariasis Patients in Umudike, Abia Stae, Nigeria. Ann Clin Lab Res Vol.5:No.3:193.

\section{Abstract}

Ascaris lumbricoides is the causative organism that causes ascariasis. Ascariasis is an intestinal infection that is becoming common in this part of the World due to poor sanitation. It is causing a lot of harm to our people who treat other things which may not be the real cause of their disease. The study was done to determine the alterations in haematological parameters. The study was done in a secondary health institution in Umudike. A total of sixty five (65) subjects were recruited for the study, thirty (30) subjects were ascariasis patients (Test) and thirty five (35) subjects were apparently healthy individuals (control). Venous EDTA anticoagulated blood was used for the haematological assays. The results were analysed with student t-test and significance level set at $P<0.05$. The results showed significant decrease $(P<0.05)$ in haemoglobin, PCV, RBC, WBC and neutrophil of the ascariasis subjects compared to the control and significant increase $(P<0.05)$ in lymphocyte, monocyte and eosinophil. This shows that ascariasis infection leads to anaemia and leukopaenia. The immunity of the patients is challenged. Cytokines are secreted leading to inflammatory reaction and hypersentivity reactions. Proper treatment should be given to the affected patients immediately and should eat blood building foods such as vegetables.

Keywords: Alterations; Haematological parameters; Ascariasis; Umudike

\section{Introduction}

Parasitic infections as reported by Orji et al. [1] are responsible for some of the most frequent disease conditions in tropical and sub-tropical communities. Infection caused by intestinal parasites is a public health hazard in Nigeria [2]. The term gastrointestinal parasites refer to the parasites that infect man, whose adult or trophozoite stage inhabit the intestines of man. Their ova, larva, and cysts are frequently found in human faeces. These exist almost in every species of animals and can sometimes be free-living in the form of infective eggs or larvae which are found in the soil where there are moist conditions. Gastrointestinal parasitic infections are among the most common infections worldwide [3]. These infections vary from place to place in relation to the pattern of transmission of the disease [4]. Ascariasis is a cosmopolitan intestinal parasitosis estimated to affect approximately 1.4 billion people worldwide [5]. Poor socio-economic environment is the major prevalent factor among those affected. Haematological parameter such as haemoglobin $(\mathrm{Hb})$, packed cell volume (PVC), White blood cell counts (WBC) and red blood cells are very vital in the diagnosis of diseases [6].

Uzoaru [7] opined that blood parameters help in the assessment of the health status of the individual to detect disease and also to evaluate the patient's prognosis to treatment [7]. It has been reported that mean haemoglobin level was affected by high parasitic burden.

\section{Aim}

To determine alterations in haematological parameters of ascariasis patient in Umudike, Abia State, Nigeria. 


\section{Materials and Methods}

\section{Study area}

The study was done in Umudike, Abia State, Nigeria

\section{Subjects}

A total of 65 subjects were recruited for the study, 35 subjects were diagnosed with ascariasis attending Health Services of Michael Okpara University of Agriculture, Umudike, Abia State, Nigeria and 30 subjects were apparently healthy individuals (control).

\section{Ethical consideration}

Informed consents were obtained from the subjects before the samples were collected.

\section{Statistical analysis}

The results were presented in Table 1 as mean and standard deviation and analysed using student t-test and level of significance set at $P<0.05$.

\section{Parasitological examination and data analysis}

Stool samples collected were stored in air-tight container and taken to Diagnostic Laboratory Unit, Health Services
Department of Michael Okpara University of Agriculture, Umudike, Abia State, Nigeria. It was analyzed in the laboratory by the concentration techniques as described by [8]. In each case, $2 \mathrm{gm}$ of faecal sample was respectively emulsified in formo-aline and $10 \%$ formalin. Parasite seen was identified using $\times 10$ and $\times 40$ objective respectively.

\section{Results}

The results showed significant decrease $(P<0.05)$ in haemoglobin, PCV, RBC, WBC, neutrophil of the ascariasis subjects $(12.3 \pm 0.5 \mathrm{~g} / \mathrm{dl}, 37.0 \pm 6.0 \%, 4.1 \pm 0.2 \times 1012 / \mathrm{L}, 5.2 \pm$ $0.3 \times 109 / \mathrm{L}, 68.2 \pm 8.0 \%)$ and significant increase $(\mathrm{P}<0.05)$ in lymphocyte, monocytes and eosinophil of the ascariasis subjects $(32.5 \% \pm 7.2 \%, 3.0 \% \pm 0.2 \%, 3.0 \% \pm 0.1 \%)$ compared to control subjects $(30.8 \% \pm 4.8 \%, 1.0 \% \pm 0.1 \%, 0 \%)$.

\section{Discussion}

The results showed suppression in red cell line, WBC and neutrophil and elevated lymphocyte, monocyte and eosinophil. This show that ascariasis causes anaemia in the patients and elicits hypersentivity reactions and eosinophil is increased which will lead to increased immunoglobin $E$ (IgE). This condition may have a suppressive effect on the bone marrow of the infected patients as seen in the results. The relationship between parasitic infections and allergies has been reported by some other researchers [9-12].

Table 1 Showing haematological parameters of the subjects.

\begin{tabular}{|c|c|c|c|}
\hline Parameters & Ascariasis subjects & Control & Significance level \\
\hline Haemoglobin (g/dl) & $12.3 \pm 0.5$ & $15.0 \pm 0.9$ & $P<0.05$ \\
\hline $\mathrm{PCV}(\%)$ & $37.0 \pm 6.0$ & $45.0 \pm 4.2$ & $P<0.05$ \\
\hline $\operatorname{RBC}\left(\times 10^{12} / \mathrm{L}\right)$ & $4.1 \pm 0.2$ & $5.0 \pm 0.4$ & $P<0.05$ \\
\hline WBC $\left(\times 10^{9} / L\right)$ & $5.2 \pm 0.2$ & $6.2 \pm 0.2$ & $P<0.05$ \\
\hline Neutrophil (× 109/L) & $61.5 \pm 4.0$ & $68.2 \pm 8.0$ & $P<0.05$ \\
\hline Lymphocyte $\left(\times 10^{9} / \mathrm{L}\right)$ & $32.5 \pm 7.2$ & $30.8 \pm 4.8$ & $P<0.05$ \\
\hline Monocyte $\left(\times 10^{9} / \mathrm{L}\right)$ & $3.0 \pm 0.2$ & $1.0 \pm 0.1$ & $P<0.05$ \\
\hline Eosinophil $\left(\times 10^{9} / \mathrm{L}\right)$ & $3.0 \pm 0.1$ & $0.0 \pm 0.0$ & $P<0.0$ \\
\hline
\end{tabular}

Clinical symptoms of ascariasis may mimic the symptoms of allergic disease and some authors suggest the participation of intestinal parasites in immunomodulation [11]. IgE antibody is an important component of the immune resistance to helminth infections. It is assumed that parasitic infections with a high total IgE may protect against allergens, by blocking mast cell response to an allergen, which is explained by a lower percentage of positive skin prick tests in people with infection [13]. Thus, the parasites can protect against allergies, especially among chronically infected patients by increasing the secretion of regulatory immunoreactive cytokines [14].

Blood cells and their values are important indicators of disease conditions in individuals. A decrease or increase in their values gives an insight to the health condition of a person [6]. This is similar to the findings of Ameh et al. [15] who stated from his observation that haematocrit result showed low PCV in more of the infected than non-infected people. The haeamotological parameters of ascariasis patient should monitored to avoid anaemia which lead to increased morbidity and mortality rate. The clinical symptoms should guide the medical laboratory scientist in the diagnosis.

\section{Conclusion}

Ascaris lumbricoides infection is shown to cause decrease in haemoglobin, packed cell volume, red blood cell, total white 
cell and elevated lymphocyte, monocyte and eosinphil. The condition exposes the patient to anaemia and increased morbidity and mortality rate. It also proved that there will be increased cytokines that will be released by the increased lymphocytes and monocytes which will lead to inflammation and enhance the pathogenesis of the infection. The physicians should take cognizance of this when treating the patients infected with Ascaris lumbricoides. There will be allergy due to increased eosinophils by elevating immunoglobin E (IgE). Clinical history of the patients should be properly taken and accurate examination of stool samples of the patients done in the laboratory when ascariasis is suspected and the haematological parameters monitored.

\section{References}

1. Orji NM, Okafor JE, Obi RK, Ezeigbo EU, Opara KN (2012) Intestinal parasite and nutritional status among school children of Mmiata-Anam, Anambra State, Nigeria. The Internet J of Parasitic Dis 10: 1528-1536.

2. Alakija W (1986) Prevalence of intestinal parasites in the stools of people in a rural area of Nigeria. Ann Trop Med Parasitol 80: 545-547.

3. Compton DWJ, Savioli L (1993) Intestinal parasitic infection and urbanization. Bull World Health Organization 71: 1-7.

4. LukaL SA, Ayogi, Umoh JU (2006) Helminthiasis among primary school in Use LGA, Kaduna State, Nigeria. Nig J Para 21: 109116.

5. Sarinas PS, Chitkara RK (1997) Ascariasis and hookworm. Seminars in respiratory infections 12: 130-137.

6. Dage JV, Lewis SM (1984) Practical haematology (6th edn) Church Will Livingstone Edingburgh London, UK. pp. 7-49.
7. Uzoaru SC (2007) Basic realities of haematology and bgs, Copy Craft International Ltd., Abakaliki, Ebonyi State, Nigeria.

8. Cheesbough M (2005) Medical laboratory manual for tropical Countries. (2nd edn), Cambridge University Press, UK. pp. 179-186.

9. Calvert J, Burney P (2010) Ascaris, atopy, and exercise-induced bronchoconstriction in rural and urban South African children. J Allergy Clin Immunol 125: 100-105.

10. Pinelli E, Willers SM, Hoek D, Smit HA, Kortbeek LM, et al. (2009) Prevalence of antibodies against Ascaris suum and its association with allergic manifestations in 4-year-old children in The Netherlands: the PIAMA birth cohort study. Eur J Clin Microbiol Infect Dis 28: 1327-1334.

11. Turner JD, Jackson JA, Faulkner H, Behnke J, Else KJ, et al. (2008) Intensity of intestinal infection with multiple worm species is related to regulatory cytokine output and immune hyporesponsiveness. J Infect Dis 197: 1204-1212.

12. Hopkin J (2009) Immune and genetic aspects of asthma, allergy and parasitic worm infections: evolutionary links. Parasite Immunol 31: 267-273.

13. Van Riet E (2008) Protection from skin test reactivity by helminth infections: Trichuris trichiura induces protection in the long term. Clin Exp Allergy 38: 1702-1704.

14. Figueiredo CA, Barreto ML, Rodrigues LC, Cooper PJ, Silva NB, et al. (2010) Chronic intestinal helminth infections are associated with immune hyporesponsiveness and induction of a regulatory network. Infect Immun 78: 3160-3167.

15. Ameh IG, Onah JA, Amao RM (2004) Intestinal parasitiasis: Positive cases and low haematocrit among pregnant women at the antenatal clinic, Vom Nigeria. Nig J Parasitol 25: 33-37. 